\title{
MINAT PESERTA DIDIK DALAM MENGIKUTI PELAJARAN DI SEKOLAH MENENGAH PERTAMA
}

\author{
HENDRI \\ Dosen Pada Fakultas Keguruan Dan Ilmu Pendidikan Universitas Muhammadiyah Palangkaraya
}

\begin{abstract}
ABSTRAK
Penelitian ini bertujuan untuk mengetahui dan mendeskripsikan minat peserta didik dalam mengikuti pelajaran. Penelitian ini dilakukan di SMP Negeri 1 Binjai tahun pelajaran 2010/2011.

Metode pendekatan penelitian yang digunakan adalah pendekatan kuantitatif, yang semua informasi dan data diwujudkan dalam bentuk kuantitatif atau dengan angka, analisisnya berdasarkan angka tersebut dengan menggunakan analisis statistik. Populasi penelitian berjumlah 536 peserta didik. Teknik pengambilan sampel dengan proporsional random sampling dengan mengambil $15 \%$ dari jumlah populasi atau 80 peserta didik. Metode pengumpulan data untuk mengungkap variabel digunakan angket. Menurut cara keleluasaan menjawabnya termasuk angket tertutup, dan menurut bentuknya termasuk angket bentuk pilihan. Analisis data digunakan rumus persentase sebagaimana pendapat Zanzawi Soejoeti (1986).

Hasil penelitian menunjukkan bahwa (1) minat peserta didik dalam mengikuti pelajaran disebabkan adanya perasaan senang pada pelajaran, adanya perhatian pada pelajaran, dan adanya perasaan/sikap positif pada pelajaran, (2) bila dilihat dari urutan tingkat minat peserta didik dalam mengikuti pelajaran dari yang tertinggi sampai yang terendah persentasenya adalah: (a) adanya perasaan/sikap positif pada pelajaran sebesar $35,00 \%$ dengan kategori cukup tinggi, (b) adanya perhatian terhadap pelajaran sebesar $27,92 \%$ dengan kategori cukup tinggi, dan (c) adanya perasaan senang pada pelajaran sebesar $26,07 \%$ dengan kategori cukup tinggi, dan (3) secara keseluruhan bahwa minat peserta didik dalam mengikuti pelajaran di SMP Negeri 1 Binjai tahun pelajaran 2010/2011 dalam kategori cukup tinggi dengan persentase sebesar $29,66 \%$.
\end{abstract}

Kata kunci: Minat Peserta Didik.

\section{ABSTRACT}

This study aimed to figure out and describe learners' interest in learning process. This study was done in SMP Negeri 1 Binjai academic year 2010/2011.

The method approach was quantitative, where all informations and data realized in quantitative or numbers, the analysis based on the statistic analysis. The population were 536 learners. Technique of sample collection with propotional random sampling by taking $15 \%$ from the population numbers or 80 learners. The method of data collection to identify the variable used questioner. Based on the answer discretion it is close questioner. The data were analyzed by using percentage formula, it is relevant to Zanzawi Soejoeti (1986)

The result showed that (1) learners' interest in learning process caused of sense of excitement, attention, and positive attitude to the lesson. (2) based on the level of interest in learning process the higher and the lower category as follow: (a) positive attitude to lesson $35,00 \%$ in high category, (b) learners" attention to lesson $27,92 \%$ in high category, and (c) sense of excitement to lesson $26,07 \%$ in high category, and (3) it can be concluded that learners' interest in learning process in SMP Negeri 1 Binjai academic year $2012 / 2011$ in high category with percentage $29,66 \%$.

Keywords : learners' interest

\section{PENDAHULUAN}

Majunya pendidikan Indonesia selalu berkaitan dengan kualitas sumber daya manusia, yang dituntut untuk memiliki kecerdasan, akal budi dan ketaqwaan kepada Tuhan Yang Maha Esa. Dalah satu cara untuk memenuhi tuntutan 
tersebut dengan cara memperbaiki sistem pendidikan karena pembangunan di bidang pendidikan merupakan bidang yang strategis dalam penyiapan sumber daya manusia. Oleh karena itu dunia pendidikan teru menerus diperbaiki arah dan sistemnya.

Pendidikan pada dasarnya ditujukan untuk mengembangkan seluruh aspek kehidupan peserta didik baik dari segi pengetahuan, keterampilan maupun sikap, dengan harapan peserta didik supaya menjadi manusia seutuhnya yang bertaqwa kepada Tuhan Yang Maha Esa, berakhlak mulia, cerdas dan bertanggung jawab sebagai manusia.

Untuk mencapai tujuan tersebut, maka sistem pendidikan dilakukan secara komprehensif atau menyeluruh sehingga pendidikan tidak semata-mata diarahkan untuk mengembangkan aspek pengetahuan semata, akan tetapi juga aspek-aspek yang berkenaan dengan perilaku, sikap maupun minat. Dalam pendidikan disekolah khususnya dalam proses belajar mengajar, minat peserta didik untuk mengikuti pelajaran merupakan salah satu hal mendasar untuk mewujudkan prestasinya. Dalam kaitannya dengan hal tersebut, Winkel mengemukakan bahwa "Minat adalah kecendrungan yang menetap dalam subjek untuk tertarik pada bidang atau hal tertentu dan merasa senang berkecimpung dalam hal itu" (Winkel, 1994:182).

Minat menbuat seseorang merasa tertarik pada hal tertentu atau objek. Hal tertentu yang menarik minatnya akan menimbulkan perasaan senang pada dirinya. Oleh sebab itu minat peserta didik untuk mengikuti pelajaran merupakan hal yang perlu ditanamkan sedini mungkin sejak memasuki sekolah, karena minat merupakan pendorong seseorang dalam mencapai cita-cita sehingga dengan adanya minat akan membuat peserta didik lebih bersemangat untuk mencapai prestasinya. Oleh sebab itu minat untuk mengikuti pelajaran merupakan hal yang sangat penting bagi peserta didik karena merupakan salah satu faktor yang ikut menentukan keberhasilan belajarnya, dan minat tersebut dapat muncul karena ada perasaan senang pada pelajaran, ada perhatian terhadap pelajaran, dan adanya perasaan/sikap positif terhadap pelajaran.dalam kenyataanya tidak semua peserta didik memiliki minat yang baik atau minat yang tinggi dalam mengikuti semua mata pelajaran sehingga berakibat terjadi kekurangseriusan dalam mengikuti pelajaran tersebut di kelas yang akhirnya berdampak negatif terhadap prestasi belajarnya, bahkan masih banyak peserta didik yang belum mampu mengkondisikan dirinya untuk mengikuti pelajaran dengan baik disekolahnya. Demikian pula informasi yang diperoleh dari para wali kelas di SMP Negeri 1 Binjai tahun pelajaran 2010/2011 yang mengatakan bahwa peserta didik banyak yang tidak serius dalam mengikuti mata pelajaran sejarah, pasif dalam mengikuti mata pelajaran sejarah di kelas, tidak bedah berada di dalam kelas, dan juga sering terjadi keterlambatan peserta didik untuk mengerjakan tugas-tugas dari guru, maupun kuran disiplin dengan waktu belajar dikelas, sehingga kegiatan belajar mengajar menjadi kurang efektif.

Berdasarkan gambaran permasalah tersebut, peneliti ingin mengetahui secara pasti minat peserta didik dalam mengikuti pelajaran disekolah sehingga peneliti tertarik mengambil judul penelitian "Studi Tentang Minat Peserta 
Didik dalam Mengikuti Pelajaran di SMP Negeri 1 Binjai Tahun Pelajaran 2010/2011. Berdasarkan latar belakang yang telah dipaparkan, maka cakupan penelitian ini difokuskan pada masalah, bagaimanakah minat peserta didik dalam mengikuti pelajaran.

Setiap usaha yang dilakukan dengan sengaja, tentunya mempunyai maksud dan tujuan yang ingin dicapai, adapun penelitian ini bertujuan untuk mengetahui minat peserta didik dalam mengikuti pelajaran.

\section{METODOLOGI PENELITIAN}

Penetuan metode penelitian berkaitan dengan jenis pendekatan yang akan dilaksanakan. Menurut Lexy J. Moleong (1993: 11) bahwa"penlitian deskriptif adalah penelitian yang memaparkan tentang karakteristik daya dari variabel yang diteliti. Jadi, penelitian deskriptif merupakan sutu penelitian yang hasil dari penelitian dapat diukur dan disajikan dalam bentuk angka". Jenis penelitian ini adalah penelitian deskriptif yang menguraikan atau mendeskripsikan suatu fakta. Adapun populasi penelitian ini adalah peserta didik SMP Negeri 1 Binjai tahun pelajaran 2010/2011 berjumlah 536 peserta didik, dengan tekhnik pengambilan sampel yang digunakan adalah proporsional random sampling, yaitu pengambilan sampel secara acak melalui undian sesuai dengan kelasnya masing-masing. Cara pengambilan sampel dalam penelitian ini adalah dengan cara membuat daftar semua anggota populasi, kemudian diundi secara acak. Mengigat dalam penlitian ini jumlah populasi dibawah 1000 siswa, maka sampel yang digunakan dalam penelitian ini sebesar $15 \%$, atau setelah dilakukan perhitungan terhadap 536 peserta didik sebagai populasi penelitian ini diperoleh sebanyak 80 peserta didik sebagai sampel.

Dalam penlitian ini hanya menggunakan satu variabel yaitu minat peserta didik dalam mengikuti pelajaran. Untuk mengungkap variabel tersebut digunakan indikator-indikator sebagai berikut:

1. Perasaan senang pada suatu objek

2. Adanya perhatian pada suatu objek

3. Ada sikap positif terhadap objek

Sedangkan teknik pengumpulan data yang mengungkap variabel dalam penelitian ini digunakan metode angket atau questioner. Angket yang digukan dalam penelitian ini ditinjau dari cara menjawabnya termasuk angket semi terbuka karena jawaban sudah disediakan tetapi dimungkinkan responden dapat memberikan jawaban tambahan. Bila ditinjau dari jawaban atau infornasi yang diberikan responden tergolong angket langsung karena langsung diisi oleh responden yang bersangkutan. Untuk teknik anlisis data yang digunakan dalam penelitian ini adalah menggunakan rumus persentase yang dikemukakan oleh Zanzawi Soejoeti (1986: 1) sebagai berikut:

$$
P=\frac{F}{N} \times 100 \%
$$

Keterangan:

$\mathrm{P}=$ Persentase

$\mathrm{F}=$ Frekuensi jawaban responden

$\mathrm{N}=$ Jumlah responden

Untuk melakukan penelitian hasil pengolahan data digunakan kriteria sebagaimana pendapat Zanzawi Soejoeti (1991: 84) pada tabel berikut ini: 


\begin{tabular}{|l|l|l|}
\hline \multicolumn{3}{|c|}{ Kriteria Penilaian } \\
\hline No & Persentase & Kategori \\
\hline 1 & $80-100 \%$ & Tinggi \\
\hline 2 & $60-80 \%$ & Cukup \\
\hline 3 & $40-60 \%$ & Agak rendah \\
\hline 4 & $20-40 \%$ & Rendah \\
\hline 5 & $0-20 \%$ & Rendah sekali \\
\hline
\end{tabular}

\section{PEMBAHASAN}

\section{Pengertian minat}

Banyak ahli yang mengemukakan definisi tentang minat, dan sering kali terdapat perbedaan diantara mereka, namun perbedaan itu justru akan menambah cakrawala pandangan tentang pengertian minat itu sendiri. Slameto (1995: 180) mengatakan bahwa "Minat adalah suatu rasa lebih suka dan rasa keterikatan pada suatu hal atau aktivitas, tanpa ada yang menyuruh". Winkel (1994: 30) menyebutkan bahwa "Minat adalah kecendrungan yang menetap dalam subjek untuk merasa tertarik pada bidang atau hal dan merasa senang berkecimpung dalam bidang itu".

Berdasarkan definisi tersebut, peneliti menyimpulkan bahwa minat adalah kecendrungan yang menetap pada diri subjek atau individu yang menyebabkan ia merasa tertarik pada suatu bidang/aktivitas tertentu yang dapat memberikan kepuasan kepadanya.

\section{Faktor-faktor yang mempengaruhi minat}

Masalah minat merupakan hal yang berhubungan dengan aspek-aspek kejiwaan seseorang. Dengan demikian faktor-faktor yang mempengaruhi minat seseorang tidak berbeda dengan masalah-masalah yang mempengaruhi kejiwaan seseorang. Slameto mengatakan bahwa "Faktor-faktor yang dapat mempengaruhi minat dapat berasal dari dalam diri maupun dari luar diri seseorang" (Slameto, 1995: 65). Berdasarkan pendapat tersebut menunjukkan bahwa minat merupakan suatu aspek yang dirasakan jiwa seseorang dan timbulnya dipengaruhi oleh faktorfaktor yang berasal dari dalam diri maupun dari luar diri seseorang.

\section{Pengertian Pelajaran}

Pelajaran adalah bagian dari pendidikan, yaitu ilmu yang dipelajari atau diajarkan kepada peserta didik agar bisa mendapatkan ilmu pengetahuan dengan jalan belajar supaya bisa melatih daya-daya yang ada pada peserta didik seperti mengamati, menanggapi, mengingat, mengkhayal, merasakan dan sebagainya. Pelajaran atau bahan belajar untuk sekolah tingkat SMP ada beberapa macam atau jenis bidang studi seperti: Agama, IImu Sosial Dasar, IImu Alamiah Dasar, Matematika, PPKN, Bahasa Indonesia, Bahasa Inggris, Teknilogi Informasi dan Komunikasi, Penjaskes dan Keterampilan.

\section{Pengertian belajar}

Menurut Slameto (1995: 14) bahwa "belajar didefinisikan sebagai suatu kegiatan yang disengaja untuk mengubah tingkah laku sehingga diperoleh kecakapan baru". Sedangkan Dewi Ketut Sukardi (1993: 16) bahwa "belajar adalah usaha murid membimbing dirinya keperubahan situasi maupun kemajuan dalam proses perkembangan jiwa, sikap pribadi pada umumnya". Dalam belajar anak wajib mengubah situasi, pengetahuan dan daya jiwa, keterampilan maupun sikap dan kepribadian untuk dirinya sendiri. Oleh karena itu siswa belajar harus dengan seluruh potensinya. Jadi tidak hanya dengan pikiran saja. hal ini dapat dilihat setelah guru mengajar dengan segala metode dan media, kemudia tugas anaklah yang mengolah, mengingat materi tersebut. 
Dari uraian tersebut, dapat disimpulkan bahwa belajar adalah segala daya upaya dalam pengubahan situasi maupun kemajuan yang menuju ke arah perkembangan intelek, jiwa serta sikap pribadi.

\section{Faktor penunjang keberhasilan belajar}

Selameto (1995: 198) mengemukakan bahwa "faktor - faktor yang mempengaruhi keberhasilan belajar meliputi: Faktor stimulus belajar, Metode belajar, Bimbingan dalam belajar, Motivasi, Faktor individual. Berdasarkan uraian tersebut, dapat dsimpulkan bahwa faktor penunjang keberhasilan belajar adalah segala sesuatu yang baik pada diri seseorang, seperti adanya stimulus, metode belajar yang benar, bimbingan belajar yang benar, kematangan serta kesehatan jasmani dan rohani.

Rekapitulasi Data Hasil Penelitian Minat Peserta Didik Dalam Mengikuti Pelajaran

Rekapitulasi data hasil penelitian minat peserta didik dalam mengikuti pelajaran disajikan sebagaimana tabel berikut.

Rekapitulasi data hasil penelitian minat peserta didik dalam mengikuti pelajaran

\begin{tabular}{|c|c|c|c|}
\hline \multirow{2}{*}{ No Item } & \multicolumn{2}{|c|}{ Frekuensi Jawaban } & \multirow{2}{*}{ Jumlah } \\
\cline { 2 - 3 } & Ya (A) & Tidak (B) & \\
\hline 1 & 12 & 68 & 80 \\
\hline 2 & 16 & 64 & 80 \\
\hline 3 & 30 & 50 & 80 \\
\hline 4 & 18 & 62 & 80 \\
\hline 5 & 40 & 40 & 80 \\
\hline 6 & 20 & 60 & 80 \\
\hline 7 & 10 & 75 & 80 \\
\hline 8 & 14 & 66 & 80 \\
\hline 9 & 48 & 32 & 80 \\
\hline 10 & 18 & 62 & 80 \\
\hline 11 & 22 & 58 & 80 \\
\hline 12 & 8 & 72 & 80 \\
\hline 13 & 24 & 54 & 80 \\
\hline 14 & 10 & 70 & 80 \\
\hline 15 & 22 & 58 & 80 \\
\hline 16 & 26 & 54 & 80 \\
\hline 17 & 36 & 44 & 80 \\
\hline 18 & 32 & 48 & 80 \\
\hline 19 & 42 & 38 & 80 \\
\hline 20 & 28 & 52 & 80 \\
\hline
\end{tabular}


Rekapitulasi data hasil penelitian minat peserta didik dalam mengikuti pelajaran berdasarkan perhitungan persentase

\begin{tabular}{|c|r|r|r|}
\hline \multirow{2}{*}{ No Item } & \multicolumn{2}{|c|}{ Frekuensi Jawaban } & \multirow{2}{*}{ Jumlah } \\
\cline { 2 - 3 } & Ya (A) & Tidak (B) & 100 \\
\hline 1 & 15,00 & 85,00 & 100 \\
2 & 20,00 & 80,00 & 100 \\
3 & 37,50 & 62,50 & 100 \\
4 & 22,50 & 77,50 & 100 \\
5 & 50,00 & 50,00 & 100 \\
6 & 25,00 & 75,00 & 100 \\
7 & 12,50 & 87,50 & 100 \\
8 & 17,50 & 82,50 & 100 \\
9 & 60,00 & 40,00 & 100 \\
10 & 22,50 & 77,50 & 100 \\
11 & 27,50 & 72,50 & 100 \\
12 & 10,00 & 90,00 & 100 \\
13 & 30,00 & 70,00 & 100 \\
14 & 12,50 & 87,50 & 100 \\
15 & 27,50 & 72,50 & 100 \\
16 & 32,50 & 67,50 & 100 \\
17 & 45,00 & 55,00 & 100 \\
18 & 40,00 & 60,00 & 100 \\
19 & 52,50 & 47,50 & 100 \\
20 & 35,00 & 65,00 & \\
\hline
\end{tabular}

Penilaian Tingkat Minat Peserta Didik Dalam Mengikuti Pelajaran

Penilaian tingkat minat peserta didik dalam mengikuti pelajaran

\begin{tabular}{|c|c|l|}
\hline $\begin{array}{c}\text { No } \\
\text { Item }\end{array}$ & $\begin{array}{c}\text { Persentase minat peserta didik } \\
\text { dalam mengikuti pelajaran }\end{array}$ & \multicolumn{1}{|c|}{ Kategori } \\
\hline 1 & 15,00 & Rendah \\
2 & 20,00 & Rendah \\
3 & 37,50 & Cukup tinggi \\
4 & 22,50 & Rendah \\
5 & 20,00 & Cukup tinggi \\
6 & 25,00 & Rendah \\
7 & 12,50 & Rendah \\
8 & 17,50 & Rendah \\
9 & 60,00 & Tinggi \\
10 & 22,50 & Rendah \\
11 & 27,50 & Cukup tinggi \\
12 & 10,00 & Rendah \\
13 & 30,00 & Cukup tinggi \\
14 & 12,50 & Rendah \\
15 & 27,50 & Cukup tinggi \\
16 & 32,50 & Cukup tinggi \\
17 & 45,00 & Cukup tinggi \\
18 & 40,00 & Cukup tinggi \\
19 & 52,50 & Tinggi \\
20 & 35,00 & Cukup tinggi \\
\hline
\end{tabular}


Tabel tersebut menunjukan bahwa tingkat minat peserta didik untuk mengikuti pelajaran bervariasi dari kategori rendah sampai dengan kategori tinggi. Dari 20 item yang digunakan dalam penelitian ini, terdapat kategori rendah sebanyak 9 item, kategori cukup tinggi sejumlah 9 item dan kategori tinggi berjumlah 2 item.

\section{Pembahasan}

1. Adanya perasaan senang pada pelajaran

2. Minat peserta didik dalam mengikuti pelajaran karena ada rasa senang dengan pelajaran di SMP Negeri 1 Binjai tahun pelajaran 2010/2011 sebesar 26,07\% termasuk kategori cukup tinggi. Hasil tersebut diperoleh dari rata-rata jumlah persentase dari kategori cukup tinggi ditambah dengan jumlah persentase kategori rendah dan dibagi dua.

3. Adanya perhatian terhadap pelajaran

Minat peserta didik dalam mengikuti pelajaran karena adanya perhatian terhadap pelajaran di SMP Negeri 1 Binjai tahun pelajaran 2010/2011 sebesar 27,92\% termasuk kategori cukup tinggi. Hasil tersebut diperoleh dari rata-rata jumlah persentase dari kategori tinggi ditambah dengan jumlah persentase kategori cukup tinggi dan ditambah dengan jumlah persentase kategori rendah dan dibagi tiga.

4. Perasaan/sikap positif pada pelajaran

Minat peserta didik dalam mengikuti pelajaran karena perasaan/sikap positif pada pelajaran di SMP Negeri 1 Binjai tahun pelajaran 2010/2011 sebesar 35,00\% termasuk kategori cukup tinggi. Hasil tersebut diperoleh dari rata-rata jumlah persentase dari kategori tinggi ditambah dengan jumlah persentase kategori cukup tinggi dan ditambah dengan jumlah persentase kategori rendah dan dibagi tiga.

Dari hasil penelitian apabila dikelompokkan berdasarkan indikator variabel maka dapat direkapitulasikan sebagai berikut.

Rekapitulasi minat peserta didik dalam mengikuti pelajaran berdasarkan indikator variabel.

\begin{tabular}{|l|l|c|l|}
\hline No & Indikator Variabel & Persentase (\%) & Kategori \\
\hline & Adanya perasaan senang pada pelajaran & 26,07 & Cukup tinggi \\
& Adanya perhatian terhadap pelajaran & 27,92 & Cukup tinggi \\
& Adanya perasaan/sikap positif pada pelajaran & 35,00 & Cukup tinggi \\
\hline & Rata-rata & 29,66 & Cukup tinggi \\
\hline
\end{tabular}


Berdasarkan hasil penelitian tersebut maka dapat diketahui secara umum bahwa minat peserta didik dalam mengikuti pelajaran di SMP Negeri 1 Binjai tahun pelajaran 2010/2011 dengan kategori cukup tinggi sebesar $29,66 \%$.

\section{KESIMPULAN}

Setelah dilakukan analisis data, maka penelitian ini dapat disimpulkan sebagai berikut.

1. Minat peserta didik dalam mengikuti pelajaran di SMP Negeri 1 Binjai tahun pelajaran 2010/2011 memiliki tiga indikator yaitu adanya perasaan senang pada pelajaran, adanya perhatian pada pelajaran dan adanya perasaan/sikap positif pada pelajaran.

2. Bila dilihat dari urutan tingkat minat peserta didik dalam mengikuti pelajaran di SMP Negeri 1 Binjai tahun pelajaran 2010/2011 dari yang tertinggi sampai yang terendah persentasenya adalah sebagai berikut. (1) adanya perasaan/sikap positif terhadap pelajaran sebesar $35,00 \%$ dengan kategori cukup tinggi, (2) adanya perhatian terhadap pelajaran sebesar $27,92 \%$ dengan kategori cukup tinggi, dan (3) adanya perasaan senang terhadap pelajaran sebesar $26,07 \%$ dengan kategori cukup tinggi.

3. Secara keseluruhan bahwa minat peserta didik dalam mengikuti pelajaran di SMP Negeri 1 Binjai tahun pelajaran 2010/2011 dalam kategori cukup tinggi dengan persentase sebesar $29,66 \%$.

\section{DAFTAR PUSTAKA}

Dewi Ketut Sukardi. 1993. Proses Bimbingan Penyuluhan. Jakarta: Rineka Cipta.

Lexy J. Moleong. 1993. Penelitian Pendidikan. Bandung: Sinar Baru.

Nuryanti. 1990. Minat Belajar. Surabaya: Karunika.

Slameto. 1995. Belajar dan Faktor-faktor yang Mempengaruhinya. Jakarta: Rineka Cipta.

Winarno Surachmad. 1992. Pengantar Interaksi Belajar Menagajar. Bandung: Transito.

Winkel, W.S. 1994. Bimbingan Konseling di Institusi Pendidikan. Jakarta: Gramedia. 